\title{
Determination of Some Population Dynamical Parameters of Planiliza abu (Heckel, 1843) from Ceyhan River Basin*
}

\section{Sevil BİRECİKLİGİL**, Burak SEÇER, Muhammed KELLECİ, Ertan ARAS, Erdoğan ÇIÇEK}

Nevşehir Hacı Bektaş Veli University, Faculty of Art and Sciences, Department of Biology, Nevşehir, TURKEY

$\begin{array}{ll}\text { Geliş } & : 20.10 .2016 \\ \text { Kabul } & : 27.01 .2017\end{array}$

Research Article / Araștırma Makalesi

**Corresponding author e-mail: sevilsungur@nevsehir.edu.tr

E-Dergi ISSN: $1308-7517$

\begin{abstract}
This study was carried out in order to determine population parameters of Planiliza abu in August 2014, May and July 2015 in Azaplı Lake and Kartalkaya Dam Lake, Ceyhan River Basin. A total of 370 specimens were analyzed. Age of the specimens ranged from 0 to VI. age groups and dominant age group was III $(30.81 \%)$. Total length varied from $4.0-23.1 \mathrm{~cm}$ with the mean of $14.17 \pm 3.11 \mathrm{~cm}$ and total weight ranged from 1.06 to 160.10 with the mean of $39.49 \pm 24.95 \mathrm{~g}$. Length-weight relationship were estimated $W=0.0114 L^{3.022}$. Estimated population parameters were calculated as $L_{\infty}: 27.87 \mathrm{~cm}, k: 0.189$ year $^{-1}, t_{o}:-1.09$ year, $\Phi^{\prime}: 2.89$ and $K: 1.13$ for the population. Mortality and exploitation rates were also estimated as $Z: 0.40, M: 0.33, F: 0.07$ and $E: 0.17$, respectively. In the light of these values there were no over fishing pressure on the population.
\end{abstract}

Keywords: Azaplı Lake, Kartalkaya Dam Lake, age and growth, mortality rates, exploitation rate.

\section{Ceyhan Havzası Planiliza abu (Heckel, 1843) Populasyonuna Ait Bazı Populasyon Parametrelerinin Belirlenmesi}

\section{Özet}

Bu çalışma Ağustos 2014, Mayıs ve Temmuz 2015 tarihlerinden Ceyhan Havzasında yer alan Azaplı Gölü ve Kartalya Barajındaki Planiliza abu populasyonuna ait parametrelerin belirlenmesi amacıyla yapılmıştır. Örneklenen 370 bireyin yaşlarının 0 ile VI. yaş grupları arasında değişim gösterdiği ve baskın olan yaş grubunun III. yaş grubu $(\% 30,81)$ olduğu belirlenmiştir, Çalışmada kullanılan bireylerin $4,0-23,1 \mathrm{~cm}$ total boya ve 1,06-160,10g total ağırlığa sahip oldukları belirlenmiş olup ortalama boy ve ağırlık değerleri ise sirasıyla $14,17 \pm 3,11 \mathrm{~cm}$ ve $39,49 \pm 24,95 \mathrm{~g}$ olarak hesaplanmıştır. Boy-ağırlık ilişkisi $W=0,0114 L^{3,022}$ ve bazı populasyon parametreleri ise $L_{\infty}: 27,87 \mathrm{~cm}, k: 0,189 \mathrm{yll}^{-1}, t_{o}:-1,09$ y1l, $\Phi^{\prime}: 2,89$ ve $K: 1,13$ olarak tahmin edilmiştir. Ölüm oranları ve sömürülme düzeyi ise $Z: 0,40, M: 0,33, F: 0,07$ ve $E: 0,17$ olarak hesaplanmış olup bu veriler 1şı̆̆ında populasyon üzerinde herhangi bir av baskısının söz konusu olmadığı ortaya çıkmaktadır.

Anahtar kelimeler: Azaplı Gölü, Kartalkaya Barajı, yaş ve büyüme, ölüm oranları, sömürülme oranı.

*The study was carried out as a part of the projects founded by Nevsehir HBV University Scientific Project Unit, No: $13 F 34$.

\section{INTRODUCTION}

The mullets or grey mullets belongs to a family Mugilidae and order of ray-finned fish found worldwide in coastal temperate and tropical waters, and in some species in fresh water. Mullets have served as an important source of food in Mediterranean Europe since Roman times. They are migrating in coastal marine waters, estuaries and rivers in the Indo-Pacific region and East Atlantic, including the Mediterranean and Black Sea. This species formerly placed in the genus Liza but Durand et al. (2012) placed in the genus 
Planiliza (Durand and Borsa, 2015; Jouladeh-Roudbar et al., 2015; Eschmeyer et al., 2016). Planiliza $a b u$ is a freshwater mullet, found in streams, rivers, drains, channels, canals, lakes, reservoirs and ponds, including fish farms (Coad, 2016). This species is found in schools. The diet is diverse but the main component is organic detritus and sand grains which are probably ingested when searching for detritus and the species may be ingesting micro-organisms associated with the sand. Aquatic plant parts, phytoplankton and aquatic insects and their larvae are also important parts of the diet. Other prey includes crustaceans, mollusks and worms. Very small fish consume eggs. This species is a day feeder (Coad, 2016).

This species is found in rivers flowing to the northern and eastern Persian Gulf, and is most common in Iran, Iraq, and Pakistan. It is found far upriver in Syria and Turkey, within the Tigris and Euphrates system (Coad, 2016). The species migrates towards upstream the Tigris at a period extending from August to late February (Ünlü et al., 2000). It has also been reported from the Orontes river systems draining to the Mediterranean (Yalcin-Ozdilek, 2003; Ay and Ozcan, 2016) where it is introduced and established. None of the previous studies about the fish fauna of Ceyhan River Basin was reported for this species and it was probably introduced to dams and reservoirs by aqua culturists or fish stocking facilities (Zebari, 2015). The aim of this study was to investigate some population parameters including age, growth, mortality and exploitation rates of the species.

\section{MATERIALS and METHODS}

This study was carried out in June-August 2010, May-July 2013 from Ceyhan River Basin in Azapl L Lake $\left(37^{\circ} 45^{\prime} 01.00^{\prime \prime} \mathrm{K}-37^{\circ} 33^{\prime} 19.93^{\prime \prime} \mathrm{K}\right)$ and Kartalkaya Dam Lake $\left(37^{\circ} 29^{\prime} 17.64^{\prime \prime} \mathrm{K}-37^{\circ} 16^{\prime} 15.51^{\prime \prime} \mathrm{K}\right)$. A total of 370 specimens were caught using gill nets with mesh sizes between $10 \mathrm{~mm}$ and $50 \mathrm{~mm}$. Collected specimens were fixed in $10 \%$ formalin and transferred to laboratory.

In order to determine the population parameters, the total length and weight were determined to the nearest $1 \mathrm{~mm}$ and $0.01 \mathrm{~g}$, respectively in each specimen. The scale samples were removed from the left side of the body ventral to the dorsal fin for the age determination. Scales were soaked in water and examined independently twice with no reference to the previous readings and without any knowledge of the length or weight of the fish under the stereo binocular microscope. The precision was measured by the percentage of agreement between the two readings (Chang, 1982). The assessment of age was based on the determination of the number of annuli on each scale.

The length-frequency data were plotted with $1 \mathrm{~cm}$ length intervals. The length-weight relationships (L-WRs) were determined according to the allometric equation $W=a * L^{b}$ (Sparre and Venema, 1998). In this equation, $W$ is total weight, $L$ is total length, $a$ and $b$ are regression constants. Growth in length and weight were expressed in terms of the von Bertalanffy equation $L_{t}=L_{\infty}\left[1-\mathrm{e}^{-k(t-t o)}\right]$. The growth parameters $L_{\infty}, k$ and $t_{o}$ were estimated using the Least Squares Method recommended by Sparre and Venema (1998).

The length-length relationships (L-LRs) are useful for standardization of length type. The LLRs with total length among different body lengths were estimated using the method of least squares to fit a simple linear regression model as $Y=a+b X$, where $Y$ : various body lengths, $X$ : total length, $a$ : proportionality constant and $b$ : regression coefficient. Percentage of growth rate in length was calculated by the formula $G R=$ 
$\left(L_{t+1} / L_{t}\right) * 100$. Where $L_{t}$ : fish length at age $\mathrm{t}, L_{t+1}$ : fish length at age $\mathrm{t}+1$. Von Bertalanffy growth curves (Bertalanffy, 1938): $L_{t}=L_{\infty}\left[1-\mathrm{e}^{-k(t-t)}\right]$

The growth performance index $\left(\Phi^{\prime}\right)$ was calculated using the formula (Pauly and Munro, 1984): $\Phi^{\prime}=\log k+2 \log L_{\infty}$. Fulton's Condition Factor $(\mathrm{K})$ were calculated by following equations: $K=100 \frac{W}{L^{3}}$ where; $W$ : total weight and $L$ : total length (Sparre and Venema, 1998).

The instantaneous rate of total mortality coefficient $Z$ was estimated using Beverton and Holt's Z Equation (Beverton and Holt, 1957): $Z=k \frac{\left(L_{\infty}-\bar{L}\right)}{\left(\bar{L}-L^{\prime}\right)}$, where; $\bar{L}$ is the mean length of the entire catch, $L^{\prime}$ is the lower limit of corresponding length intervals (Sparre and Venema, 1998). The natural mortality coefficient $(M)$ was estimated following Pauly's empirical formula (Pauly, 1980), linking the natural mortality with the von Bertalanffy parameters, $L_{\infty}(\mathrm{cm}), k$ and mean annual temperature $(T)$ of water in habitat (mean annual temperature of Ceyhan River tributaries reported as $12.65^{\circ} \mathrm{C}$ by Karakaya et al., 2014): $\log 10 M=-0.0152-0.279 \log 10 L_{\infty}+0.6543 \log 10 k+0.463 \log 10 T$. Fishing mortality rates $(F)$ was calculated as the difference between $Z$ and $M(Z=F+M)$. The value of the average annual exploitation rate $(E)$ was obtained by $E=F / Z$ (Sparre and Venema, 1998).

Correspondence between empirical data and an expected distribution was tested by $\mathrm{Khi}^{2}$ test. The $b$ value was tested by t-test to verify that it was significantly different from the isometric growth $(b: 3)$.

\section{RESULTS}

A total of 434 specimens were caught during the sampling period and of age of these 318 specimens were determined. Age of $P$. $a b u$ varied from 0 to VI age groups and most frequent age groups were III (30.8\%), IV (18.1\%) and II (16.2\%), respectively (Table 1). The total length ranged from 4.0 to $23.1 \mathrm{~cm}$ with the mean of $14.17 \pm 3.11 \mathrm{~cm}$ and total weight varied from 1.06 to $160.10 \mathrm{~g}$ with the mean of $39.49 \pm 24.95 \mathrm{~g}$. It was evident that $P$. $a b u$ grew rapidly in their two years after which growth rate declined.

Table 1. Age, length and weight-frequency distribution of $P . a b u$ from Ceyhan River Basin

\begin{tabular}{|c|c|c|c|c|c|c|c|c|}
\hline \multirow[b]{2}{*}{ Age } & \multirow[b]{2}{*}{$\mathrm{n}$} & \multirow[b]{2}{*}{$\% \mathrm{n}$} & \multicolumn{3}{|c|}{ Total length (cm) } & \multicolumn{2}{|c|}{ Total weight (g) } & \multirow[b]{2}{*}{$\begin{array}{c}\text { Growth } \\
\text { rate } \\
(\%)\end{array}$} \\
\hline & & & Mean & Range & $\begin{array}{c}\text { Growth } \\
\text { rate } \\
(\%)\end{array}$ & Mean & Range & \\
\hline 0 & 31 & 8.38 & $7.68 \pm 0.99$ & $4.0-9.4$ & & $8.03 \pm 1.61$ & $1.06-9.68$ & \\
\hline I & 56 & 15.14 & $9.71 \pm 1.13$ & $9.4-13.4$ & 26.43 & $13.66 \pm 5.58$ & $9.94-28.08$ & 70.1 \\
\hline II & 60 & 16.22 & $13.9 \pm 1.01$ & $12.2-15.7$ & 43.15 & $33.49 \pm 6.97$ & $22.46-49.06$ & 145.2 \\
\hline III & 114 & 30.81 & $15.04 \pm 0.88$ & $13.1-16.5$ & 8.20 & $41.41 \pm 7.50$ & $26.73-59.18$ & 23.6 \\
\hline IV & 67 & 18.11 & $16.10 \pm 0.92$ & $14.1-18.7$ & 7.05 & $48.97 \pm 8.31$ & $34.43-77.68$ & 18.3 \\
\hline $\mathrm{V}$ & 33 & 9.92 & $18.15 \pm 1.21$ & $16.3-20.9$ & 12.73 & $75.17 \pm 17.37$ & $52.21-118.32$ & 53.5 \\
\hline VI & 9 & 2.43 & $21.17 \pm 1.31$ & $19.6-23.1$ & 16.64 & $132.93 \pm 22.15$ & $102.83-160.10$ & 76.8 \\
\hline$\Sigma$ & 370 & & $14.17 \pm 3.11$ & $4.0-23.1$ & & $39.49 \pm 24.95$ & $1.06-160.10$ & \\
\hline
\end{tabular}


The length-weight relationship and von Bertalanffy growth parameters for $P$. $a b u$ are presented in Figure 1. The relationship is determines as $W=0.0114 L^{3.022}$ (95\% CI of $b$ : 2.980-3.064). The $b$ value was not significantly different from than $3.0(\mathrm{p}<0.01)$, which indicates isometric growth of $P$. $a b u$.

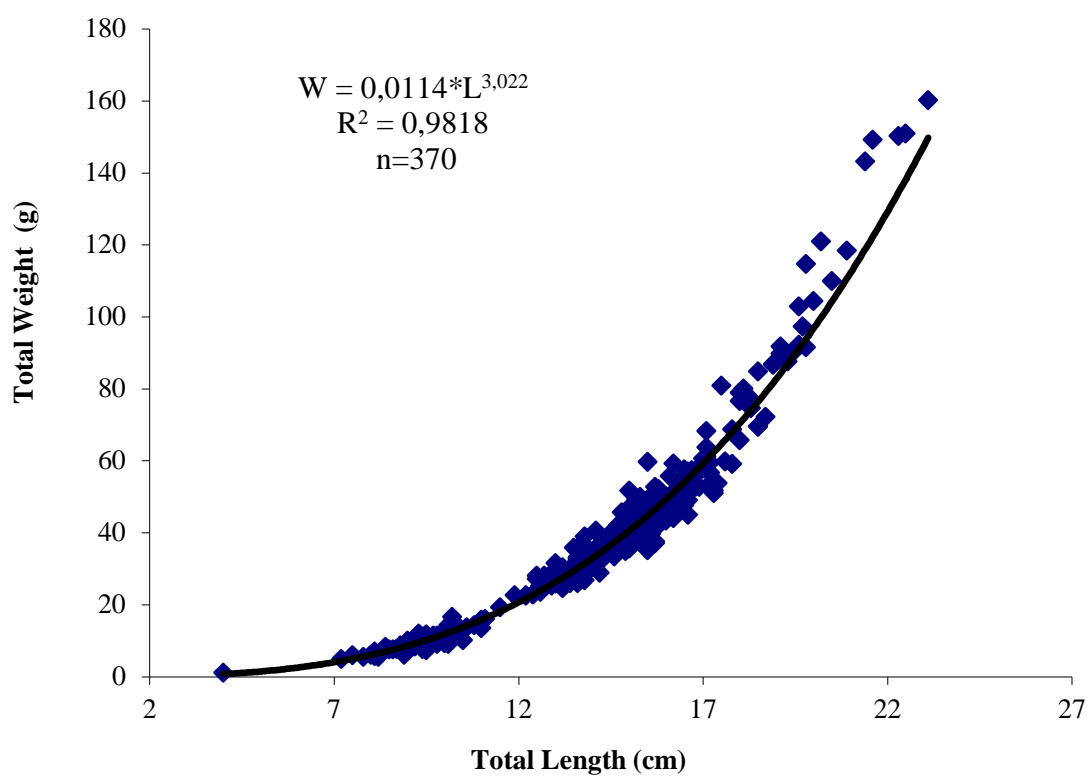

Figure 1. Length-weight relationship of $P . a b u$ from Ceyhan River Basin

The LLRs with total length among different body lengths were obtained as $\mathrm{FL}=(0.9385 * \mathrm{TL})-0.2274$ and $\mathrm{SL}=(0.8183 * \mathrm{TL})-0.1467$. Relationship equations among different body length parameters were found highly significant $(\mathrm{p}<0.01)$.

The von Bertalanffy growth parameters estimated as follows $L_{\infty}=27.87 \mathrm{~cm}, W_{\infty}=$ $360.31 \mathrm{~g}, k=0.189$ year $^{-1}$ and $t_{0}=-1.09$ year. The von Bertalanffy growth parameters calculated using the mean total length and total weight at ages were; $L t=27.87\left[1-\mathrm{e}^{-}\right.$ $0.189(\mathrm{t}+1.09)], W=27.87\left[1-\mathrm{e}^{-0.189(\mathrm{t}+1.09)}\right]^{3.022}$. The growth performance index $\left(\Phi^{\prime}\right)$ and Fulton's Condition Factor $(K)$ were estimated as 2.89 and $1.13 \pm 0.22$, respectively.

Instantaneous total $(Z)$, natural $(M)$ and fishing $(F)$ mortalities were estimated 0.40 , 0.33 and 0.07 year $^{-1}$, respectively. The exploitation rate $(E)$ was calculated as 0.17 .

\section{DISCUSSION}

The oldest fish in this study was VI years old and the age was not determined older IV age in the previous studies. The instantaneous growth rate increased up to age II and then decreased with increasing age. Fish growth usually slows down after the onset of sexual maturity when large amount of nutrient materials periodically go into egg or sperm formation (Adams, 2014). Ünlü et al. (2000) report maturity at age 1 in Tigris River based on gonad development.

Some population parameters for $P$. abu populations are presented in Table 2. 
Table 2. Length-weight relationship and von Bertalanffy growth parameters for $P$. $a b u$ from Ceyhan River Basin

\begin{tabular}{|c|c|c|c|c|c|c|c|c|c|}
\hline $\boldsymbol{b}$ & $a$ & $\begin{array}{l}\text { Length } \\
\text { ranges }\end{array}$ & $\begin{array}{c}\boldsymbol{L}_{\infty} \\
(\mathbf{c m})\end{array}$ & $\begin{array}{c}K \\
\left(\text { year }^{-1}\right)\end{array}$ & $\begin{array}{c}t_{0} \\
\text { (year) }\end{array}$ & $\Phi^{\prime}$ & $\boldsymbol{K}$ & Ecosystem & References \\
\hline 2.794 & - & - & 29.8 & 0.19 & - & 2.33 & - & $\begin{array}{l}\text { Al-Hammar } \\
\text { Marsh }\end{array}$ & Na'ama, 1982 \\
\hline 3.213 & 0.0075 & $8.7-19.8$ & 31.0 & 0.136 & -4.799 & - & - & $\begin{array}{l}\text { Mehaijeran } \\
\text { Creek }\end{array}$ & $\begin{array}{l}\text { Mhalsen and } \\
\text { Yousif, } 1989\end{array}$ \\
\hline 3.181 & - & - & 21.4 & 0.52 & - & 2.38 & - & Shatt Al-Basrah & Wahab, 1986 \\
\hline 2.700 & - & - & - & - & - & - & - & Diyala River & $\begin{array}{l}\text { Khalaf et al., } \\
1986\end{array}$ \\
\hline 3.21 & 0.136 & - & - & - & - & - & - & Babylon & $\begin{array}{l}\text { Al-Asadiy et } \\
\text { al., } 2000\end{array}$ \\
\hline 3.03 & 0.123 & - & - & - & - & - & - & Babylon & $\begin{array}{l}\text { Al-Asadiy et } \\
\text { al., } 2000\end{array}$ \\
\hline 3.01 & 0.122 & - & - & - & - & - & - & Babylon & $\begin{array}{l}\text { Al-Asadiy et } \\
\text { al., } 2000\end{array}$ \\
\hline 3.332 & 0.004 & $10.3-19.2$ & 20.4 & 0.383 & -2.51 & 2.34 & - & Tigris River & $\begin{array}{l}\text { Ünlü et al., } \\
2000\end{array}$ \\
\hline- & - & - & 21.3 & 0.53 & - & 2.38 & - & Garmat Ali River & $\begin{array}{l}\text { Abdul-Samad, } \\
2001\end{array}$ \\
\hline- & - & - & 24.0 & 0.36 & - & 2.32 & - & Euphrates River & $\begin{array}{l}\text { Abbas and Al- } \\
\text { Rudainy, } 2006\end{array}$ \\
\hline- & - & - & 23.8 & 0.52 & - & 2.47 & - & Tharthar Lake & $\begin{array}{l}\text { Shawardi, } \\
2006\end{array}$ \\
\hline 2.934 & - & - & 23.3 & 0.43 & - & 2.36 & - & $\begin{array}{l}\text { East Hammar } \\
\text { Marsh }\end{array}$ & Mutlak, 2012 \\
\hline 2.870 & 0.167 & $11.1-22.2$ & 24.6 & 0.28 & -1.36 & 2.23 & - & Atatürk Dam & $\begin{array}{l}\text { Doğu et al., } \\
2013\end{array}$ \\
\hline 2.907 & 0.0096 & $2.1-18.5$ & 20.83 & 0.323 & -0.618 & 2.23 & $0.67-1.02$ & Orontes River & Ay, 2013 \\
\hline 2.899 & 0.0149 & - & 23.2 & 0.37 & - & 2.30 & 1.00 & $\begin{array}{l}\text { East Hammar } \\
\text { Marsh }\end{array}$ & $\begin{array}{l}\text { Mohamed, } \\
2014\end{array}$ \\
\hline 2.910 & 0.0132 & - & 21.1 & 0.44 & - & 2.29 & 1.02 & Huwazah Marsh & $\begin{array}{l}\text { Mohamed, } \\
2014\end{array}$ \\
\hline 2.662 & 0.0252 & - & 20.0 & 0.41 & - & 2.22 & 0.98 & Chybaish Marsh & $\begin{array}{l}\text { Mohamed, } \\
2014\end{array}$ \\
\hline 3.158 & 0.124 & $7.3-21.8$ & 34.1 & 0.17 & -0.94 & - & 1.26 & $\begin{array}{l}\text { Deve Geçidi } \\
\text { Dam }\end{array}$ & $\begin{array}{l}\text { Elp and Kaya, } \\
2014\end{array}$ \\
\hline 3.095 & 0.010 & - & 23.65 & 0.21 & -1.54 & - & $1.21-2.41$ & Sir Reservoir & Zebari, 2015 \\
\hline 2.907 & 0.0096 & $2.2-18.5$ & 19.48 & 0.258 & -1.432 & 2.18 & $0.79-0.84$ & Orontes River & $\begin{array}{l}\text { Ay and Ozcan, } \\
2016\end{array}$ \\
\hline 3.022 & 0.0114 & $4.0-23.1$ & 27.87 & 0.189 & -1.09 & 2.89 & 1.13 & $\begin{array}{l}\text { Ceyhan River } \\
\text { Basin }\end{array}$ & This study \\
\hline
\end{tabular}

The maximum length was reported as $20 \mathrm{~cm}$ in total length by Froese and Pauly (2016). However a specimen is $22.2 \mathrm{~cm}$ in length was caught in Atatürk Dam (Turkey) and the highest total lengths $(23.1 \mathrm{~cm})$ were observed in this study. Estimated theoretical maximal length ranged from 20.0 to $34.1 \mathrm{~cm}$ in the previous studies. The $L_{\infty}$-value estimated in this study seems to be realistic.

The calculated coefficient $b$ varied among the species from a minimum of 2.662 to a maximum of 3.332 in the previous studies (Table 2). According to these values isometric and both negative and positive allometric growth were observed in $P$. abu. The value estimated in this study is median among the previously reported values and the growth of $P$. $a b u$ in Ceyhan River is isometric (b=3.022, CI: 2.980-3.064). For the variations of 
LWRs in the same species from different locations, the ecological conditions of the habits or variation in the physiology of animals, or both, are responsible (Le Cren, 1951).

The variation in the $b$ exponents for the same species could be attributed to differences in sampling, sample size or length ranges. In addition, growth increment differences in age and stage of maturity, food, as well as environmental conditions such as temperature, and seasonality can also affect the value of $b$ for the same species (Weatherley and Gill, 1987). Additionally differences are known to occur in biological features between the populations of same species living in different regions (Pazira et al., 2013). The growth is affected by many factors, such as sex, the life history strategy, food variety and availability, and temperature (Sarihan et al., 2006).

Estimated Fulton's Condition Factor $(K)$ is highly correlated with other studies. Condition Factor is the best predictor of lipid density (Neff and Cargnelli, 2004). The growth performance index ranged from 2.22 to 2.89 and the highest value of 2.89 was observed in this study.

Mortality estimates are important to fisheries management. Knowing these rates can help managers to set harvest limits to maximum sustainable yield (MSY) or optimum sustainable yield (OSY) to give the maximum benefit to the stakeholders of the resource (Sparre et al., 1989). The exploitation rates of $P$. abu estimated from East Hammar, Huwazah and Chybaish marshes (Iraq) were 0.575, 0.375 and 0.562 , respectively (Mohamed, 2014). These values indicate that there are overfishing pressure on the populations. Indeed $P . a b u$ is an important food fish in southern Iraq and commercially caught. $P$. $a b u$ is not commercially fished in Turkey but it may be consumed only locally as food for human consumption. Therefore, in this study no fishing pressure on the population from Ceyhan River Basin was determined.

\section{REFERENCES}

Abbas, L.M., \& Al-Rudainy, A.J. (2006). Ecology and biology of two freshwater fish species in Euphrates River, middle of Iraq. Proceedings of the International Conference on Underwater System Technology. Theory and Applications, Penang, Malaysia.

Abdul-Samad, S.M.S. (2001). Effect of some ecological factor on growth and reproduction of Liza $a b u$ (Heckel, 1843) in Qarmat Ali River, South Iraq. M.Sc thesis. University of Basrah, Iraq. $99 \mathrm{p}$.

Adams, A. (2014). Growth determination of selected fish species in River Hadejia, Jigawa State, Nigeria. Journal of Biology, Agriculture and Healthcare, 4(19), 40-54.

Al-Asadiy, Y.D., Mhaisen, F. T. \& Dauod, A.A.M. (2000). Observations of the age and growth of the mugilid fish Liza abu (Heckel) in a fish farm at Babylon province, mid Iraq. Ibn AlHaitham Journal for Pure and Application Science, 13(2), 20-30.

Ay, S. (2013). Some biological aspects of abu mullet (Liza abu (Heckel, 1843)) living in the River Asi (Hatay). M.Sc thesis. Mustafa Kemal University, Hatay.

Ay, S., \& Özcan, G. (2016). Some aspects of the biology of Abu mullet Liza abu (Heckel, 1843) in the Orontes River, Turkey. Croatian Journal of Fisheries, 74, 49-55. doi: 10.1515/cjf-20160011

Bertalanffy, L., Von. (1938). A quantitative theory of organic growth (inquiries on growth laws. II). Human Biology, 10, 181-213.

Beverton, R.J., \& Holt S. J. (1957). On the dynamics of exploited fish population. Fishery Investigation, 11(19), 1-533.

Chang, W.B. (1982). A statistical method for evaluating the reproducibility of age determination. Canadian Journal of Fisheries and Aquatic Sciences, 39, 1208-1210. 
Coad, B.W. (2016). Freshwater fishes of Iran. Available from: www.briancoad.com, Retrieved $14 / 06 / 2016$.

Doğu, Z., Şahinöz, E., Aral, F., \& Şevik, R. (2013). The growth characteristics of Liza (Mugil) abu (Heckel, 1843) in Atatürk Dam Lake. African Journal of Agricultural Research, 8, 44344440.

Durand, J.D., \& Borsa, P. (2015). Mitochondrial phylogeny of grey mullets (Acanthopterygii: Mugilidae) suggests high proportion of cryptic species. Comptes Rendus Biologies, 338, 266-277.

Elp, M., \& Kaya, N., (2014). A Study on Abu Mullet (Liza abu Heckel, 1843) (Diyarbakır), Turkey. Journal of Animal and Veterinary Advances, 13, 437-440.

Eschmeyer, W.N., Fricke, R., \& Van der Laan, R. (eds). Catalog of fishes: Genera, Species, References.(http://researcharchive.calacademy.org/research/ichthyology/catalog/fishcatmain .asp). Electronic version accessed 03.01.2016. [This version was edited by Bill Eschmeyer.]

Froese, R., \& Pauly, D. (2016). FishBase. Available from: www.fishbase.org. Retrieved $14 / 06 / 2016$.

Geldiay, R., \& Balık, S., 2007. Freshwater Fishes of Turkey. Freshwater Fishes of Turkey. V. Edition, Ege University Press, Bornova, Izmir, 638p.

Jouladeh-Roudbar, A., Jafari-Kenari, S., Vatandoust, S., Mousavi-Sabet, H., \& Eagderi S. (2015). Freshwater fishes of Iran; an updated checklist. Aquaculture, Aquarium, Conservation \& Legislation International Journal of the Bioflux Society 8 (6), 855-909.

Karakaya, G., Şen, B., Gölbaşı, S., \& Özer Gölbaşı, G. (2014). Changes in temperature and dissolved oxygen depth at Ataturk Dam Lake. Adryaman University Journal of Science, 4(2), 82-90.

Khalaf, A. N., Al-Yamour, K. Y., Allouse, S. B., Al-Jafary, A., \& Sadek, S. E. (1986). Age, growth, length-weight relationships and distribution of Khishni Liza abu (Heckel) (Mugilidae) in a polluted habitat. Journal of Biological Sciences Research, 17(2), 63-81.

Le Cren, E.D. (1951). The length-weight relationship and seasonal cycle in gonad weight and condition in the perch (Perca fluviatilis). Journal of Animal Ecology, 20, 201-219.

Mhalsen, F.T., \& Yousif, U.H. (1989). Age and growth of the Mugilid fish Liza abu (Heckel) from Mehaijeran Creek, Basrah. Bulletin of the Iraq Natural History Museum. 8, 147-155.

Mohamed, A.M. (2014). Stock assessment of freshwater Mullet, Liza abu (Heckel, 1843) populations in three restored Southern Marshes, Iraq. Croatian Journal of Fisheries, 72, 4854.

Mutlak, F. M. (2012). Stock assessment of some fish species from East Hammar marsh, Southern Iraq. Ph.D thesis, University of Basrah, Iraq. 193 pp.

Na'ama, A. K. (1982). Some biological aspects of two freshwater fishes, Liza abu (Heckel) and Mugil dussumieri (Val. and Cuv.) (Fam. Mugilidae) from the Horal-Hammar, North Basrah, Iraq. M.Sc. thesis, University of Basrah, Iraq. 161 pp.

Neff B.D., \& Cargnelli, L.M. (2004). Relationships between condition factors, parasite load and paternity in bluegill sunfish, Lepomis macrochirus. Environmental Biology of Fishes 71,297-304.

Pauly, D. (1980). On the interrelationships between natural mortality, growth parameters, and mean environmental temperature in 175 fish stocks, Conseil International pour l'Exploration de la Mer, 39, 175-192.

Pauly, D., \& Munro, J.L. (1984). Once more on the comparison of growth in fish and invertebrates. Fishbyte, 2, 21.

Pazira, A.R, Moghdani, S., \& Ghanbari, F. (2013). Age structure and growth of the Garra rufa (Cyprinidae), in southern Iran. International Journal of Biosciences, 3(12),115-119.

Sarihan, E., Çiçek, E., \& Toklu, B. (2006). Introduction to Fish Biology, Nobel Press, Adana.

Shawardi, A. A. (2006). Ecology and biology of Carassius carassius (L. 1758) and Liza abu (Heckel, 1843) in Tharthar lake. Ph.D thesis, University of Al-Mustansiria, Iraq, 142p. 
Sparre, P., Ursin, E., \&Venema, S.C. (1989). Introduction to tropical fish stock assessment. Part 2: Excercises Manual. FAO Fisheries Technical Paper, Rome.

Sparre, P., \&Venema, S.C. (1998). Introduction to tropical fish stock assessment. Part 1. Manual. FAO Fisheries Technical Paper. No. 306.1, Rev. 2, Rome, FAO. 407p.

Ünlü, E., Balc1, K., \& Meriç, N. (2000). Aspects of biology of Liza abu (Mugilidae) in the Tigris River (Turkey). Cybium, 24: 27-43.

Wahab, N. K. (1986). Ecology and biology of three species of mugilid fishes in Shatt Al-Basrah Canal. M.Sc. thesis, University of Basrah, Iraq, $155 \mathrm{pp}$.

Weatherley, A.H., \& Gill, H.S. (1987). The Biology of Fish Growth. Academic Press, London, England, 443p.

Yalçın-Özdilek, Ş., (2003). Occurrence of the Abu Mullet, Liza abu (Heckel, 1843) (Pisces, Mugilidae), in the Orontes River. Zoology in the Middle East, 30, 111-113.

Zebari, N.M.A. (2015). Some biological characteristics of Liza abu (Heckel, 1843) in Sir Reservoir of Ceyhan River, Turkey. MsC Thesis, Kahramanmaraş Sütçü İmam University. 